\title{
Use River Pollutant Modeling to Simulate and Predict the Change in the Damietta Branch Water Quality before and after Construction of the Ethiopian Dam
}

\author{
Mohamed K. Mostafa*, Robert W. Peters \\ Department of Civil, Construction, and Environmental Engineering, University of Alabama at Birmingham, \\ Birmingham, USA \\ Email: ${ }^{*}$ mkhaled@uab.edu
}

Received 6 June 2015; accepted 30 August 2015; published 2 September 2015

Copyright (C) 2015 by authors and Scientific Research Publishing Inc.

This work is licensed under the Creative Commons Attribution International License (CC BY). http://creativecommons.org/licenses/by/4.0/

(c) (i) Open Access

\begin{abstract}
This research was conducted on the Damietta branch of the Nile River, Egypt. The Damietta branch receives pollution loadings from the Omar-Bek drain and two power stations located along the path of the branch. The main objective of this research consisted of comparing between the Damietta branch water quality before and after the Ethiopian Dam is built. This comparison was conducted by using the river pollutant (RP) modeling. First, the actual data and the modeling results were compared in order to prove the efficiency and validity of the RP modeling. Findings from regression analysis yielded a strong positive linear relationship $(r=0.987)$ between the two results. The modeling results showed that Omar-Bek drain had less impact on the Damietta branch water quality. The results also showed that the effluent discharge from the two power stations affected water quality and aquatic life because large quantities of warm and polluted water discharged back into the Damietta branch. The results also showed that constructing the Ethiopian Renaissance Dam would slightly increase pollutants concentrations in the Damietta branch and that this increase would cause a slight deterioration in water quality.
\end{abstract}

\section{Keywords}

River Pollutant Modelling, Mass Balance, Ethiopian Dam, Damietta Branch, Egypt

\section{Introduction}

Nile River water quality is affected by industrial and agricultural wastes discharge, as well as by the sanitation

*Corresponding author.

How to cite this paper: Mostafa, M.K. and Peters, R.W. (2015) Use River Pollutant Modeling to Simulate and Predict the Change in the Damietta Branch Water Quality before and after Construction of the Ethiopian Dam. Journal of Environmental Protection, 6, 935-945. http://dx.doi.org/10.4236/jep.2015.69083 
of the cities and villages located along its path [1] [2]. The lack of sanitation services has led to the direct discharging of large amounts of untreated domestic wastewater directly to the Nile River. Studies indicate that only $24 \%$ of Egypt's population can access sewerage services [3]. In rural areas, about $5 \%$ of the population is linked to sanitation services [4]. The Nile River in Egypt divides into two branches, Damietta and Rosetta. The Damietta branch, with an estimated length of more than $242 \mathrm{~km}$ (150.37 miles), flowings from south to north and empties into the Mediterranean Sea [5]. At present, the average discharge of the Damietta branch is 30 million $\mathrm{m}^{3}$ per day. About 10.50 million $\mathrm{m}^{3} /$ day of drainage water is added to the Damietta branch at different locations, which is about $35 \%$ of its maximum discharge [6]. Along the Damietta branch are located three pollution sources: Omar-Bek drain, and Kafr-Al-Batek and Talkha power stations. Omar-Bek drain is the main source of water pollution, and Kafr-Al-Batek and Talkha power stations comprise the major sources of thermal pollution [7] [8]. Omar-Bek drain receives pollution loads from domestic, industrial, and agricultural wastes of many villages and drains located along the path of the branch [6].

Other researchers have conducted several studies assessing water quality at the Damietta branch. Soltan and Awadallah (1995) analyzed water samples collected from different locations along the Nile River [9]. The results showed elevated levels of total dissolved solids (TDS), total suspended solids (TSS), sodium $\left(\mathrm{Na}^{+}\right)$, chlorides $\left(\mathrm{Cl}^{-}\right)$, calcium $\left(\mathrm{Ca}^{2+}\right)$, lithium $\left(\mathrm{Li}^{+}\right)$, potassium $\left(\mathrm{K}^{+}\right)$, bicarbonate $\left(\mathrm{HCO}_{3}^{-}\right)$, sulfate $\left(\mathrm{SO}_{4}^{2-}\right)$, and magnesium $\left(\mathrm{Mg}^{2+}\right)$ in water samples taken from Damietta; these increased levels resulted from the discharging of effluents from industries such as cheese making factories and those involving fertilizer, textile, and pickled herring preparation. Statistical analysis of the database was established, and significant correlation coefficient values were obtained ( $r=0.61$ - 1.0). Abd-Allah et al. (1999) collected water samples from the Nile River between Mansoura City and Damietta Province [10]. The results showed elevated levels of biological oxygen demand (BOD), chemical oxygen demand (COD), ammonia $\left(\mathrm{NH}_{3}\right)$, nitrogen dioxide $\left(\mathrm{NO}_{2}\right)$, nitrate $\left(\mathrm{NO}_{3}\right)$, and phosphate $\left(\mathrm{PO}_{4}\right)$ in water samples taken from Damietta branch at Talkha city, where the branch received effluents from El-Serw and from the outlet of Talkha fertilizer plant. Ezzat and Reham (2012) conducted a study to classify Omar-Bek drain water quality and examined its impact on Damietta branch [5]. In their study, results showed that Damietta branch water quality was classified as good surface water upstream of the Omar-Bek drain and as marginal surface water downstream of the drain.

The main goals of this research consisted of evaluating the Damietta branch water quality before and after building the Ethiopian Dam, as well as defining to what extent construction the dam would affect the water quality at the Damietta branch.

\section{Materials and Methods}

This research was carried out on the Damietta branch. The study area, which encompassed about $119 \mathrm{~km}(70.2$ miles) of the Damietta branch, extended from upstream of the Omar-Bek drain and to the end of the Damietta branch (10 km before discharging in the Mediterranean Sea). Figure 1 depicts a map of the study areas.

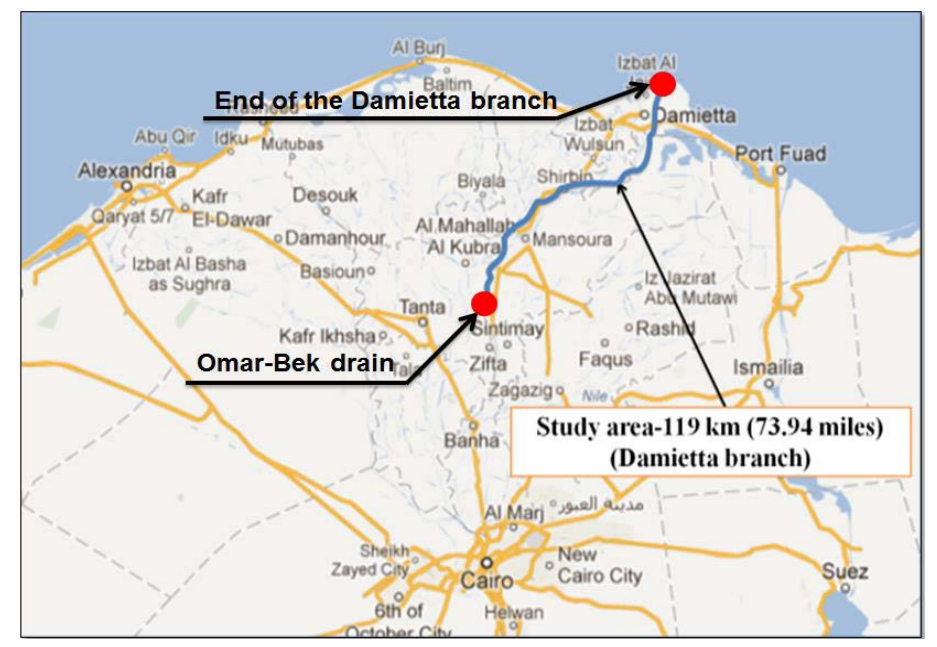

Figure 1. Study area at the Damietta branch [6]. 
River pollutant (RP) modeling was used to compare the Damietta branch water quality before and after the building of the Ethiopian dam. The RP modeling is a river water quality model used to calculate water quality parameters such as dissolved oxygen (DO), total organic carbon (TOC), $\mathrm{Cl}^{-}$, BOD, COD, TDS, TSS, $\mathrm{pH}$, and temperature [6]. It has been created by using MATLAB software to simulate pollutant transport in the Nile River delta. This software can be useful in determining the downstream distance affected by pollutant releases and aid as decision tool during the development of restrictions to be imposed on industrial, agricultural, and domestic activities in order to protect public health and prevent the spread of water-related diseases [6]. The RP modeling also helps identifying the best locations along the river for constructing water treatment plants (WTPs), wastewater treatment plants (WWTPs), and power stations [6]. To prove the efficiency and validity of the RP modeling, we obtained water samples from 21 sites along the Damietta branch in order to compare the modeling results with the field data (see Figure 2). Sample collection began December 2012 and concluded October 2013. Regression analysis for the actual and predicted values was performed with the use of Microsoft Office Excel 2010, and the correlation coefficients calculated led to the identification of the nature of correlations between the actual and predicted values. A paired-samples $t$-test was performed to evaluate the difference between the means of the actual and predicted samples. The null hypothesis $\left(\mathrm{H}_{0}\right)$ states that there are no differences between the means of the samples, while the alternate hypothesis $\left(\mathrm{H}_{1}\right)$ states that there are differences between the means of the samples.

Water samples were also collected from three point sources discharging into the Damietta branch. These data were used as input to run the RP modeling. The point sources included Omar-Bek drain, Kafr-Al-Batek power station, and Talkha power station (see Figure 2). Water samples were collected from a depth of approximately $0.3 \mathrm{~m}$ (1.0 feet) below the water surface in 2 liter polyethylene containers. Three samples were collected from each location: two samples $30 \mathrm{~m}$ from each bank and one sample from the middle section of the river. The water

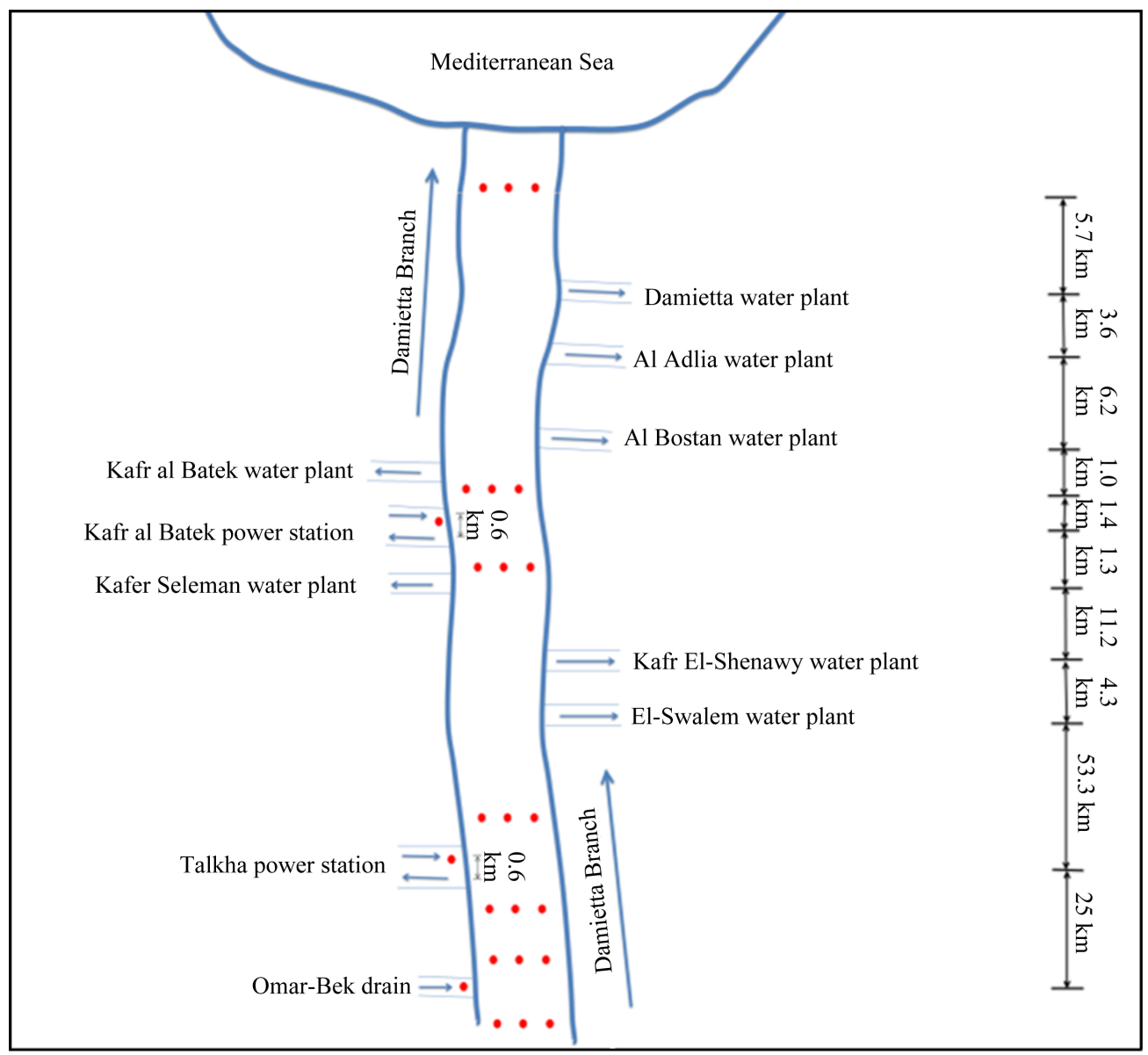

Figure 2. Sampling locations along the Damietta branch [6]. 
samples were placed into an ice chest for transfer to the laboratory. To avoid microbiological degradation of solids, we analyzed the water samples no more than 2.0 days after their collection. The analysis consisted of determining levels of DO, TOC, BOD, COD, TDS, TSS, $\mathrm{pH}$, and temperature. The samples were analyzed for different parameters according to the standard methods for wastewater analysis [11]. TDS was measured in the field by using an HM digital TDS meter. The DO, $\mathrm{pH}$, and temperature were also measured in the field by using a WTW multi 340i meter. Analysis of the other parameters took place in the Egyptian Housing Building Research Center laboratory. Test method 2540D was used for the determination of TSS. The closed reflux, titrimetric method 5220C enabled determination of the COD concentration in the samples, while the 5-day BOD Test 5210B was used in the determination of the BOD concentration in the samples. The TOC concentration was measured in the laboratory by using a Shimadzu TOC-4200 analyzer. The results were then compared with the limits specified in Egyptian law 48/1982 and EPA standards [12] [13].

In order to run the RP modeling, we calculated the flow rate upstream of Omar-Bek drain by multiplying the cross-sectional area by the flow velocity, which was measured by using a water flow probe. The river cross-section was divided into subsections, and the discharge was determined for each subsection. Because the Damietta branch has an irregular bottom, the depth was measured at a number of points across the bed. A weighted wire was used to measure the depth at any specific point. The total discharge was determined by summing the discharge levels of the subsections. The RP modeling uses the exponential and mass balance equations which enabled seasonal estimations of the values of different parameters in the Damietta branch. The mass balance helps to mathematically estimate the mass loading at any point along the Damietta branch. Consequently, the RP modeling aided in the determination of mass balance and in the identification of the mixing condition and dispersion level. The RP modeling was then used to compare the Damietta branch water quality before and after the Ethiopian dam is built. The flow rate and pollutant concentrations upstream of the Omar-Bekdrain are expected to change after building of the dam. But for the purpose of this initial modeling activity, the pollutant concentrations upstream of the Omar-Bekdrain were assumed to be constant in the two models to avoid interaction terms and confounding effects. The flow rate upstream of the Omar-Bekdrain, the only variable in the two models, is expected to decrease by about $21.6 \%$ after the dam is constructed.

\section{Results and Discussion}

\subsection{Physicochemical Analysis}

The results of the physicochemical analysis of the collected water samples are presented in Table 1. Omar-Bek drain, the main source of pollution along Damietta branch, is polluted primarily by domestic wastewater discharging from residential districts having a combined total of about 500,000 inhabitants. Results from the physicochemical analysis showed that the highest pollution levels at the outfall of Omar-Bek drain. From thid drain, water samples had an average COD concentration of about $97 \mathrm{mg} / \mathrm{Land}$ an average DO concentration of about $3.9 \mathrm{mg} / \mathrm{L}$.

Table 1. The analysis of water samples collected along the Damietta branch.

\begin{tabular}{lcccccccccc}
\hline & $\begin{array}{c}\text { Avg } \\
\text { Location/parameter }\end{array}$ & $\begin{array}{c}\text { Avg } \\
\text { flow, }\end{array}$ & $\begin{array}{c}\text { Avg } \\
\text { TDS, }\end{array}$ & $\begin{array}{c}\text { Avg } \\
\text { Temp., }\end{array}$ & $\begin{array}{c}\text { Avg } \\
\text { DO, }\end{array}$ & $\begin{array}{c}\text { Avg } \\
\mathrm{Cl}^{-},\end{array}$ & $\begin{array}{c}\text { Avg } \\
\text { BOD, }\end{array}$ & $\begin{array}{c}\text { Avg } \\
\text { COD, }\end{array}$ & $\begin{array}{c}\text { Avg } \\
\text { TOC, }\end{array}$ & $\begin{array}{c}\text { Avg } \\
\text { TSS, }\end{array}$ \\
\cline { 2 - 10 } & $\mathrm{m}^{3} / \mathrm{day}$ & & $\mathrm{mg} / \mathrm{L}$ & Celsius & $\mathrm{mg} / \mathrm{L}$ & $\mathrm{mg} / \mathrm{L}$ & $\mathrm{mg} / \mathrm{L}$ & $\mathrm{mg} / \mathrm{L}$ & $\mathrm{mg} / \mathrm{L}$ & $\mathrm{mg} / \mathrm{L}$ \\
\hline Upstream of Omar-Bek drain & $23.25 \times 10^{6}$ & 8.20 & 190.0 & 23.0 & 6.10 & 32.0 & 2.0 & 8.0 & 0.20 & 70.0 \\
Omar-Bek drain & $6.0 \times 10^{5}$ & 7.50 & 700.0 & 22.80 & 3.90 & 130.0 & 55.0 & 97.0 & 1.80 & 160.0 \\
Downstream of Omar Bek drain & $23.90 \times 10^{6}$ & 8.10 & 209.0 & 21.92 & 5.70 & 44.10 & 5.70 & 13.60 & 0.41 & 80.10 \\
Upstream of Talkha power station & $23.70 \times 10^{6}$ & 7.80 & 188.60 & 22.32 & 5.10 & 35.40 & 6.30 & 12.10 & 0.50 & 59.21 \\
Talkha power station & $3.50 \times 10^{6}$ & 7.90 & 135.0 & 35.0 & 2.33 & 64.0 & 17.0 & 38.0 & 1.15 & 70.0 \\
$\begin{array}{l}\text { Downstream of Talkha } \\
\text { power station }\end{array}$ & $23.68 \times 10^{6}$ & 7.90 & 174.50 & 29.45 & 3.80 & 55.60 & 8.20 & 17.40 & 0.80 & 66.40 \\
$\begin{array}{l}\text { Upstream of Kafr-Al-Batek } \\
\text { power station }\end{array}$ & $23.44 \times 10^{6}$ & 7.80 & 131.10 & 25.10 & 4.38 & 36.10 & 5.50 & 10.20 & 0.50 & 70.70 \\
$\begin{array}{l}\text { Kafr-Al-Batek power station } \\
\text { Downstream of Kafr-Al-Batek }\end{array}$ & $3.29 \times 10^{6}$ & 7.50 & 180.0 & 40.0 & 3.95 & 80.0 & 6.0 & 14.50 & 0.50 & 60.0 \\
$\begin{array}{l}\text { power station } \\
\text { At end of Damietta branch }\end{array}$ & $23.35 \times 10^{6}$ & 7.60 & 161.70 & 35.62 & 4.10 & 61.90 & 5.80 & 12.0 & 0.50 & 55.40 \\
\hline
\end{tabular}


Talkha power station daily discharges nearly 3.5 million $\mathrm{m}^{3}$ of cooling water to Damietta branch [6]. The elevated temperature of the discharged water, as well as the water contaminants, can negatively affect water quality and all marine life, including fish. The most common cause of fish death is thermal shock, where the water temperature increases suddenly. Because towers at Talkha power station do not function efficiently, water with a high temperature is released to the Damietta branch. The Kafr-Al-Batek power station discharges nearly 3.29 million $\mathrm{m}^{3}$ /day of water temperature elevated up to $43^{\circ} \mathrm{C}$, causing fish death in the Damietta branch. A temperature elevated up to $33^{\circ} \mathrm{C}$ was observed at the intake of Kafr-Al-Batek power station at the summer season because of the short distance between the inlet and the outlet, where the discharged cooling water is withdrawn again by the cooling system.

\subsection{The River Pollutant (RP) Modeling}

A steady state concentration and a complete vertical and lateral mixing were assumed along the Damietta branch. Also assumed was a first order decay of organic pollutants (i.e., equal to 0.1 day $^{-1}$ at $20^{\circ} \mathrm{C}$ ). The decay rate can be calculated at different water temperature as follows [14]: $\mathrm{K}_{\mathrm{T}}=\mathrm{K}_{20^{\circ} \mathrm{C}} \times 1.047^{(\mathrm{T}-20)}$. Data presented in Table 1 were applied to the RP modeling to predict flow and concentration of different parameters along the Damietta branch before the dam is built. This model provided a mass balance closure result in which the predicted flow rate at the end of the Damietta branch $\left(23,700,000 \mathrm{~m}^{3} / \mathrm{day}\right)$ was close to the actual flow rate of the branch $\left(23,210,000 \mathrm{~m}^{3} /\right.$ day). The correlation coefficient between the actual and predicted values was found to be 0.987 , as shown in Figure 3. Consequently, a significant correlation exists between both sets of data.

A paired-samples $t$-test showed that the $t$-statistic value (1.918) was located in the region of non-rejection between the critical $t$-values $( \pm 1.986)$. The parameter $p$-value $(0.0582)$ was also found to be greater than 0.05 (see Table 2). Consequently, there is no significant difference between the means of the samples; in this case, the null hypothesis could not be rejected in favor of the alternative hypothesis.

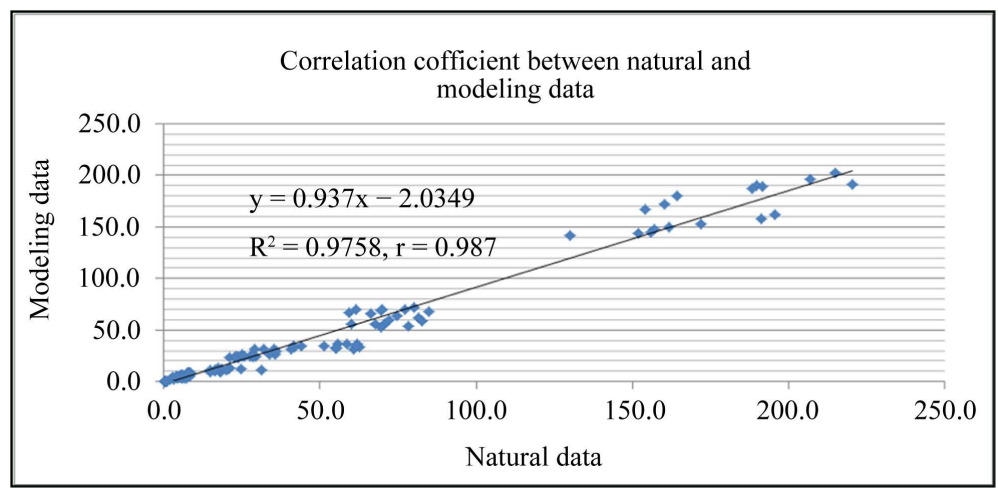

Figure 3. Relation between natural and modeling data.

Table 2. $t$-test: paired two-samples for comparison of means.

\begin{tabular}{ccc}
\hline Mix/parameter & A & B \\
Mean & 46.53 & 47.43 \\
Variance (s $\left.{ }^{2}\right)$ & 7608.26 & 7567.84 \\
Observations & 90 & 90 \\
Degrees of freedom, (df) & & 89 \\
$t$-statistic & & 1.918 \\
$t$-critical two-tail & \pm 1.986 \\
$p$-value & 0.0582 \\
Hypothesis & Null hypothesis $\left(H_{0}\right)$
\end{tabular}

$H_{0}$ : there is no difference between the means of the samples; $H_{1}$ : there is a difference between the means of the samples. 
After proving the efficiency and validity of the RP modeling, we reapplied the data presented in Table 1 to the RP modeling to predict flow and concentration of different parameters along the Damietta branch after the dam is built. The only variable in the two models consists of the water flow upstream of Omar-Bek drain, where the flow rate is expected to decrease from $23.50 \times 10^{6} \mathrm{~m}^{3} /$ day to $18.50 \times 10^{6} \mathrm{~m}^{3} /$ day after construction of the dam.

\subsection{Assessment of Water Quality before and after the Ethiopian Dam Is Built}

Egyptian law 48/1982 and EPA standards specify the following water quality standards for COD, BOD, TDS, DO, chlorides, and TSS: $\leq 10 \mathrm{mg} / \mathrm{L}, \leq 6 \mathrm{mg} / \mathrm{L}, \leq 500 \mathrm{mg} / \mathrm{L}, \geq 4 \mathrm{mg} / \mathrm{L}, \leq 500 \mathrm{mg} / \mathrm{L}$, and $\leq 20 \mathrm{mg} / \mathrm{L}$, respectively [12] [13]. As Figure 4 shows, the COD concentration upstream of Talkha power station measured about $9.5 \mathrm{mg} / \mathrm{L}$, increased to $13.66 \mathrm{mg} / \mathrm{L}$ after the Damietta branch received discharge from Talkha power station, and increased significantly by about $27.87 \%$ after the branch received discharge from the Omar-Bekdrain. The discharge from Kafr-Al-Batek power station produced a lower impact on the Damietta branch water quality; the COD concentration increased by about $4.45 \%$ after the branch received discharge from Kafr-Al-Batek power station. The COD concentration is also expected to increase by about $10.83 \%$ after construction of the Ethiopian dam. The BOD concentration along the study area remained within the limits specified in Law 48/1982 and EPA standards, as shown in Figure 5, despite increasing by about $67.3 \%, 66.17 \%$, and $6.29 \%$ after the branch received discharge from Omar-Bekdrain and from Talkha and Kafr-Al-Batek power stations, respectively. Although expected to increase by about 15\% after building of the dam, the BOD concentration will remain within the limit specified by Egyptian law and EPA standards.

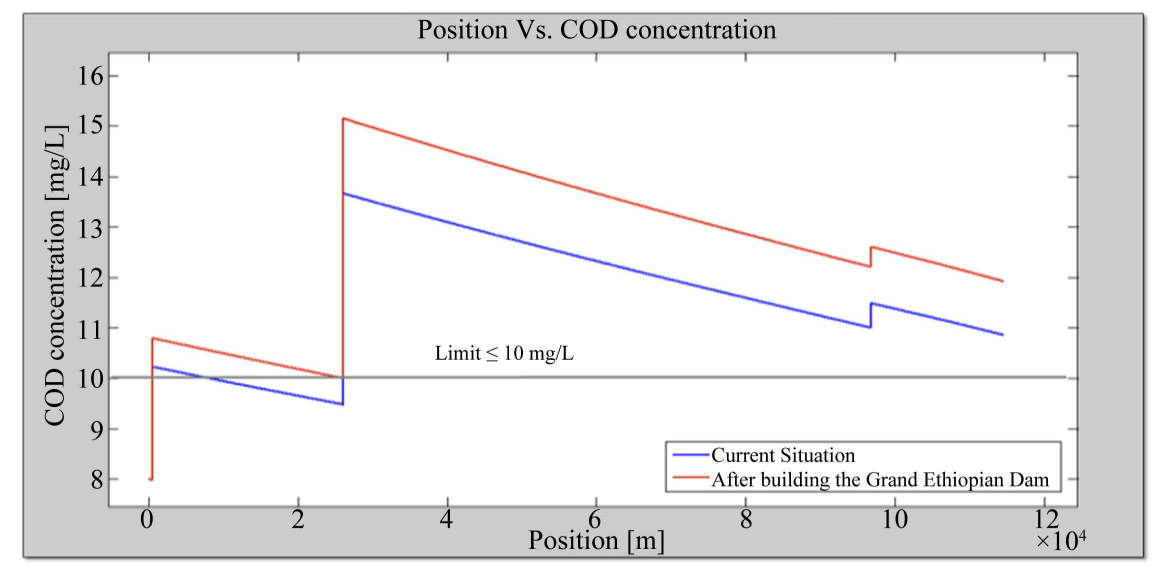

Figure 4. COD concentration along the Damietta branch before and after building of the Ethiopian dam.

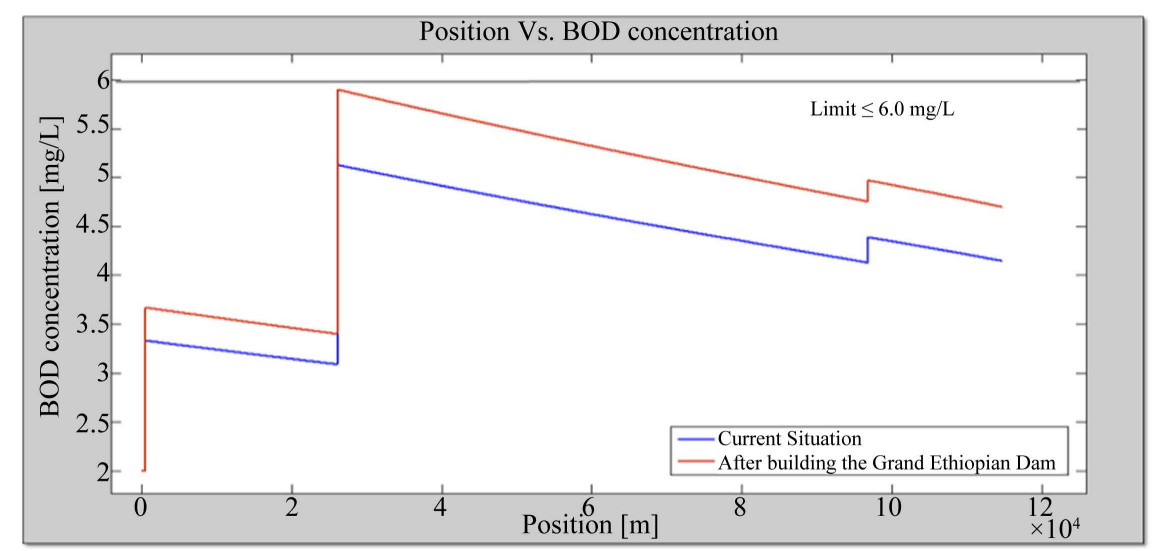

Figure 5. BOD concentration along the Damietta branch before and after building of the Ethiopian dam. 
TDS concentration along the study area did not exceed the maximum permissible limit specified in Egyptian law and EPA standards [12] [13], as shown in Figure 6. Although increasing from $189.7 \mathrm{mg} / \mathrm{L}$ to $202.6 \mathrm{mg} / \mathrm{L}$ after the branch received discharge from the Omar Bekdrain, the TDS concentration stayed within the specified limit. Discharging water from Talkha power station decreased the TDS concentration at the Damietta branch by about $4.27 \%$, whereas discharging water from Kafr-Al-Batek power station increased this concentration by about 3.38\%. The slight increase in the TDS concentration expected to occur after construction of the dam will not adversely affect the water quality at the Damietta branch (see Figure 6). The TSS concentration upstream of Omar-Bekdrain exceeded the maximum limits specified in Egyptian law and EPA standards (20 mg/L) [12] [13], as shown in Figure 7. A slight increase in TSS concentration was observed after the branch received discharge from the three point sources. Although a slight increase in the TSS concentration is expected after building of the dam, the increase will not adversely affect the water quality at the Damietta branch (see Figure 7).

Egyptian law 48/1982 specifies a water quality standard of $<3 \mathrm{mg} / \mathrm{L}$ for TOC [12]. Talkha power station daily discharges large amount of effluent possessing an elevated TOC concentration that results increased TOC concentrations downstream of the station, whereas a slight increase in TOC concentration was observed downstream of Omar-Bekdrain and Kafr-Al-Batek power station, as shown in Figure 8. After construction of the dam occurs, the TOC concentration is expected to increase by about $11.77 \%$, a figure still within the limit specified in the Egyptian law (see Figure 8). The pH value should lie between 7.0 and 8.5, according to Law 48/1982 and EPA standards [12] [13]. As Figure 9 shows, the $\mathrm{pH}$ value along the study area ranges from 7.96 to 8.20 and meets the specifications. The discharge from the three point sources did not significantly affect the $\mathrm{pH}$ value

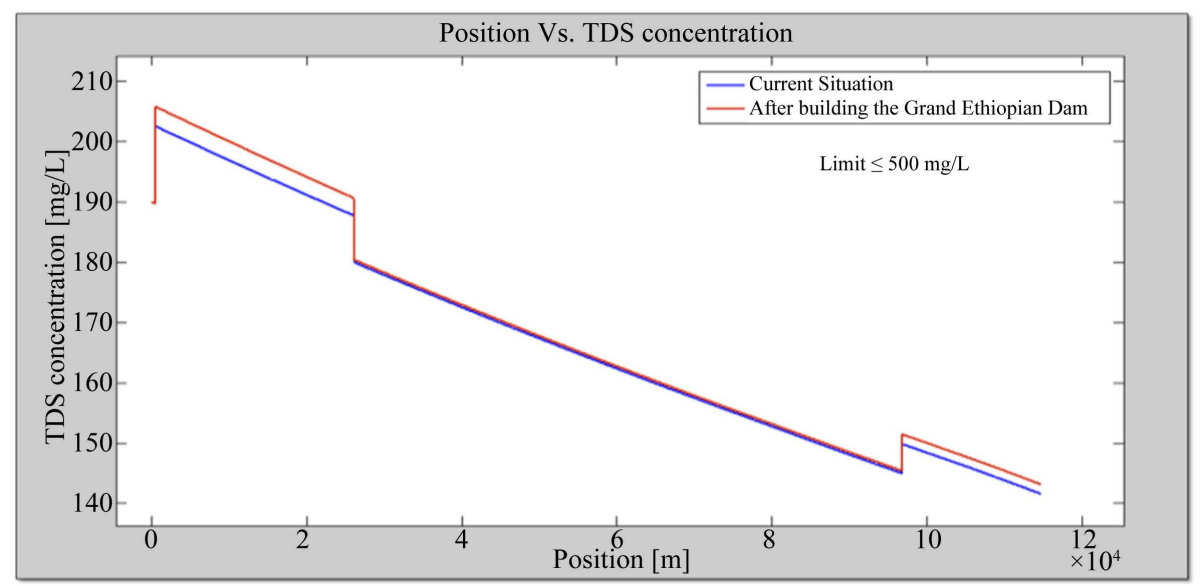

Figure 6. TDS concentration along the Damietta branch before and after building of the Ethiopian dam.

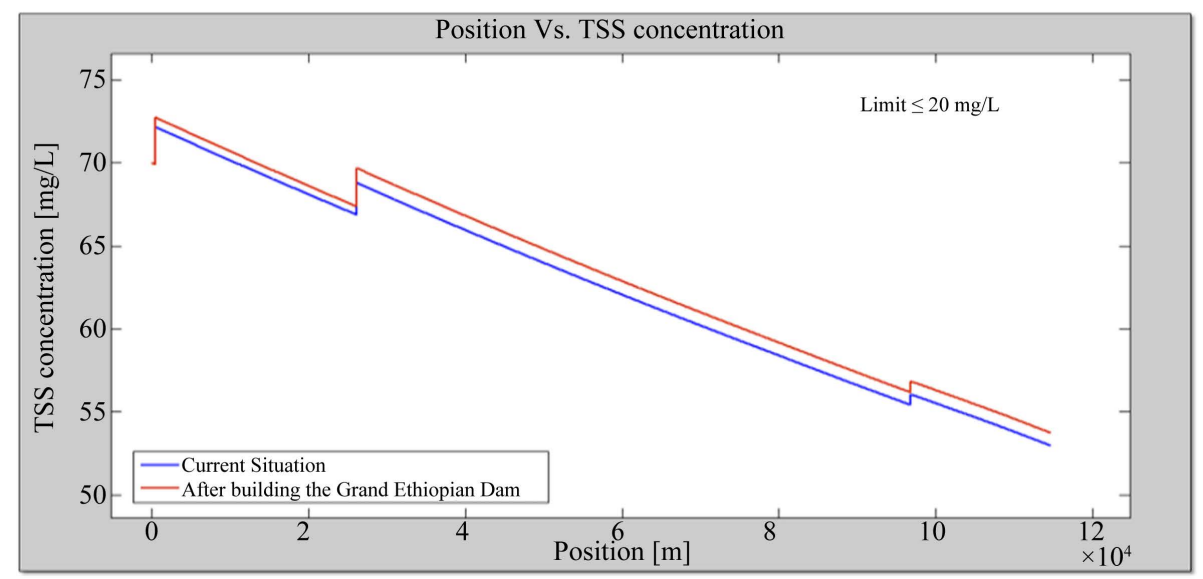

Figure 7. TSS concentration along the Damietta branch before and after building of the Ethiopian dam. 


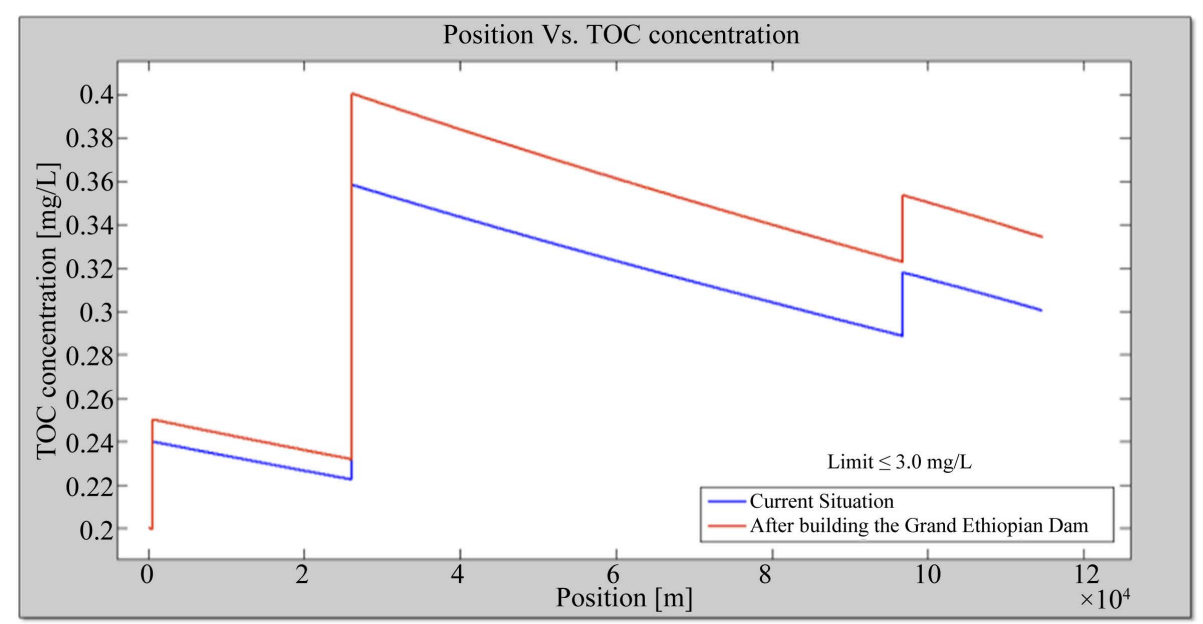

Figure 8. TOC concentration along the Damietta branch before and after building of the Ethiopian dam.

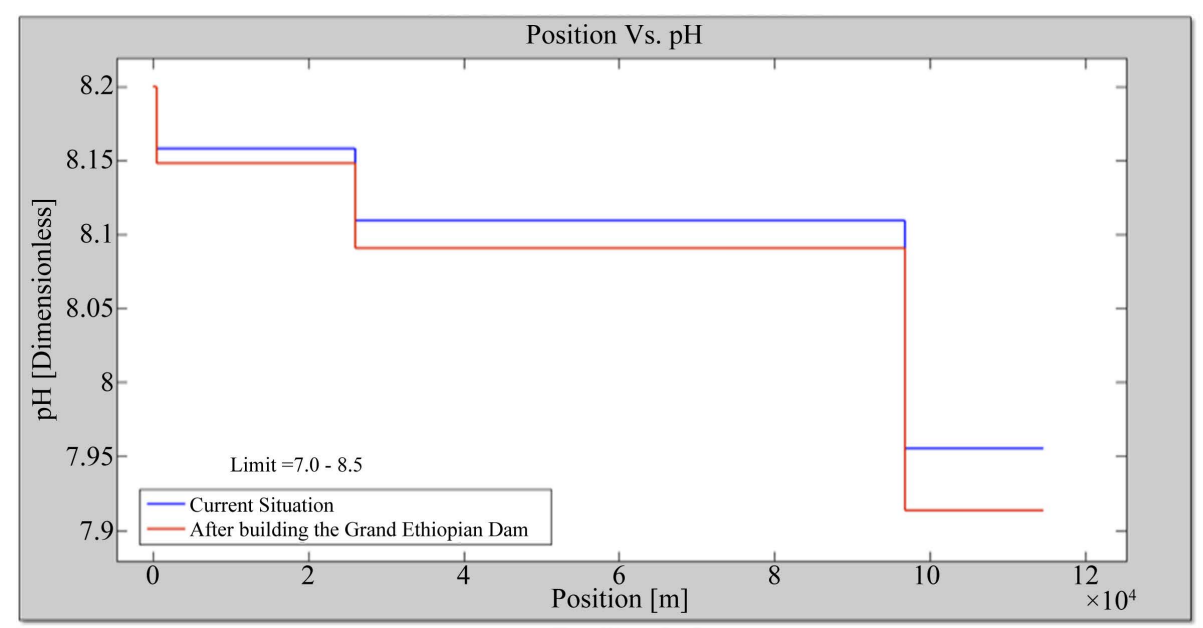

Figure 9. pH value along the Damietta branch before and after building of the Ethiopian dam.

along the Damietta branch, as shown in Figure 9. A very slight decrease in the $\mathrm{pH}$ value is expected along the Damietta branch after construction of the dam.

The water quality standard specified in Egyptian law 48/1982 and EPA standards for $\mathrm{Cl}^{-}$is $<250 \mathrm{mg} / \mathrm{L}$ [12] [13]. The $\mathrm{Cl}^{-}$concentration increased significantly from 29.50 to $36.70 \mathrm{mg} / \mathrm{L}$ downstream of Kafr-Al-Batek power station, whereas water discharged from Omar-Bekdrain and from Talkha power station increased the $\mathrm{Cl}^{-}$ concentration of the Damietta branch by about 7.73 and $14.76 \%$, respectively, all three increases remain within the specified limit (see Figure 10). After construction of the Ethiopian dam takes place, the $\mathrm{Cl}^{-}$concentration is expected to increase along the Damietta branch by about 6.2\%, a figure still within the specified limit (see Figure 10). Law 48/1982 and EPA standards also state that the DO concentration should not be less than $5 \mathrm{mg} / \mathrm{L}$ [12] [13]. Figure 11 shows that the discharge from Kafr-Al-Batek power station and Omar-Bekdrain did not significantly affect the DO concentration at the Damietta branch, whereas the discharge from Talkha power station reduced the DO concentration at the Damietta branch from 5.60 to $5.10 \mathrm{mg} / \mathrm{L}$, a level still within the specified limit. As Figure 11 also shows, the DO concentration is expected to slightly decrease after construction of the dam. Figure 12 illustrates that the discharge from Talkha power station and Omar-Bekdrain did not significantly affect the water temperature at the Damietta branch but that the discharge from Kafr-Al-Batek power station increased water temperature at the Damietta branch from $24.7^{\circ} \mathrm{C}$ to $27^{\circ} \mathrm{C}$, which results in thermal shock to aquatic life. After the dam is built, the water temperature is expected to increase by about $1.80 \%$ downstream of Talkha power station and by about 3.30\% downstream of Kafr-Al-Batek power station, as shown in Figure 12. 


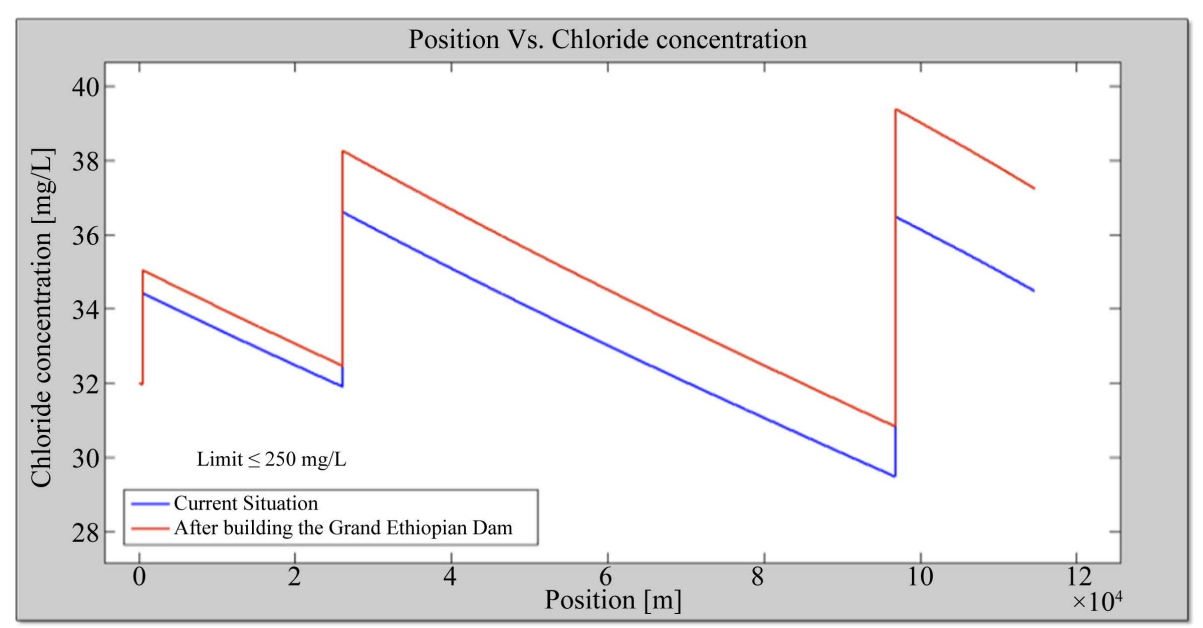

Figure 10. $\mathrm{Cl}^{-}$concentration along the Damietta branch before and after building of the Ethiopian dam.

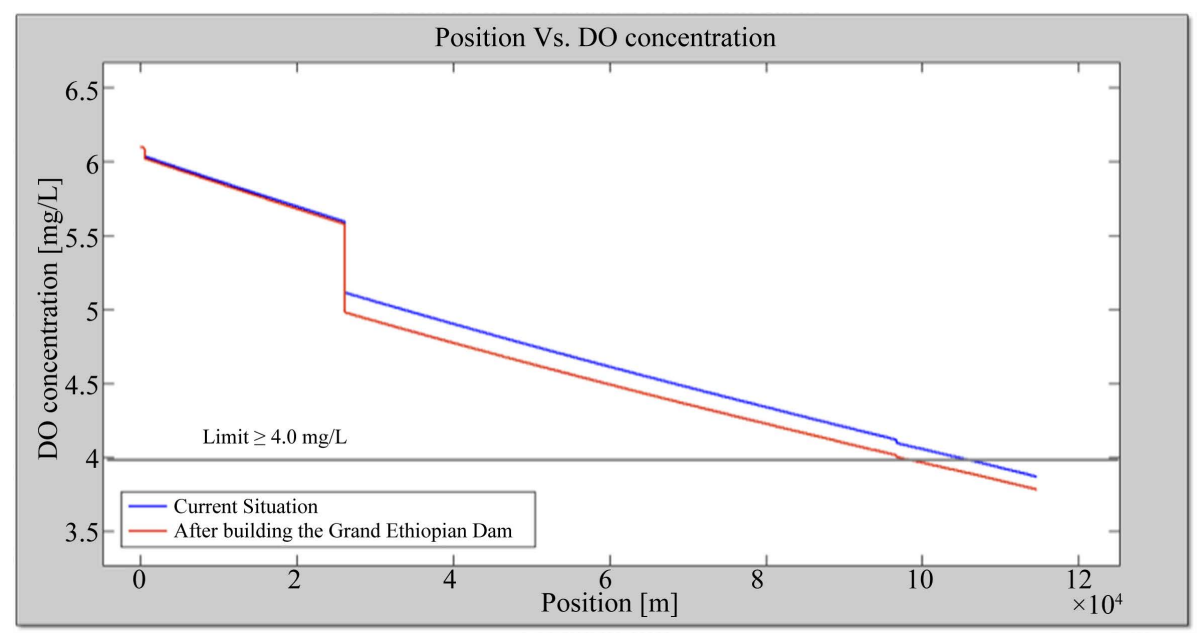

Figure 11. DO concentration along the Damietta branch before and after building of the Ethiopian dam.

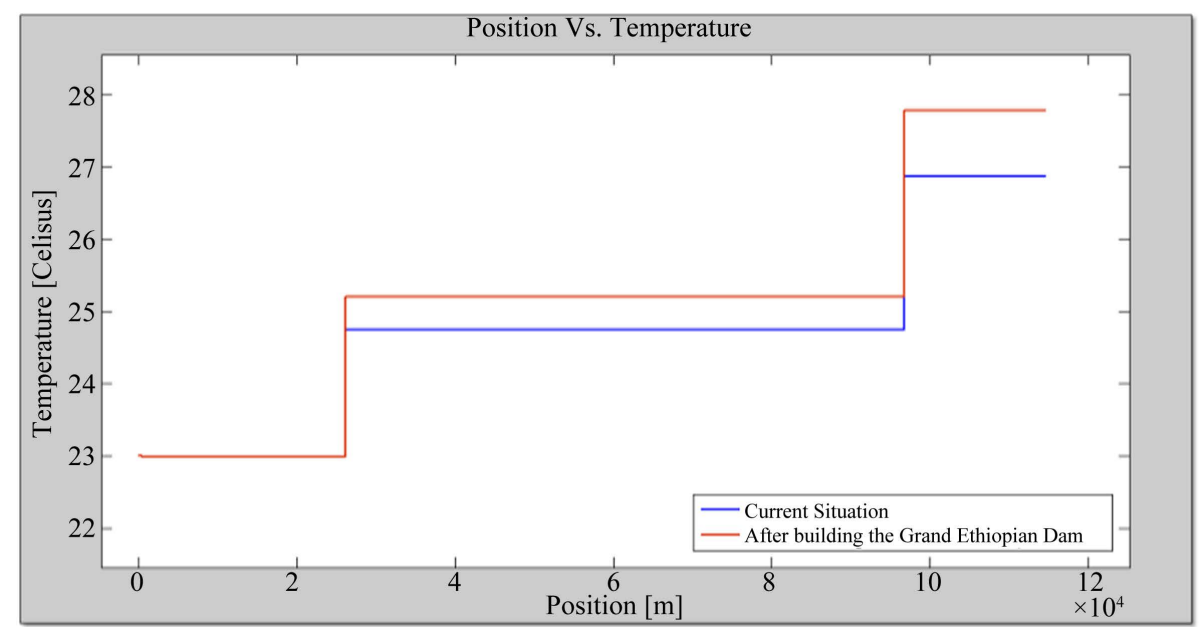

Figure 12. Water temperature along the Damietta branch before and after building of the Ethiopian dam. 


\section{Conclusions}

The Damietta branch receives pollution loadings from the Omar-Bek drain and power stations located along the path of the branch. The RP modeling results show that, of the three point sources, the Omar-Bek drain has the least impact on the Damietta branch water quality. Talkha and Kafr-Al-Batek power stations discharge nearly 9.35 million $\mathrm{m}^{3}$ /day of wastewater into the Damietta branch. In addition to the elevated temperature of the discharged water, the water pollutants can negatively affect water quality and aquatic life. Recommendations for ameliorating this affect include constructing cooling towers at Kafr-Al-Batek power station to dissipate heat and building an artificial canal that increases the distance between the inlet and the outlet to prevent the cooling water from being returned to the power station.

The RP modeling provides a useful and effective means of estimating flow and concentration of different water parameters along the Damietta branch. In this study, a significant correlation was obtained between predicted and actual values $(r=0.987)$. Consequently, a complete mixing occurs along the study area. This modeling is considered a reliable tool for water quality management in affected areas. The change in water quality caused by any future modification can also be predicted by rerunning the RP modeling. This modeling was also used to predict the change in the Damietta branch water quality after construction of the Ethiopian dam took place. The water quality at the Damietta branch will not be adversely affected by the dam because of the low concentration of pollutants and the absence of major pollution sources along the branch. The dilution factor also plays an important role in reducing pollutant concentrations along the branch. The rate of this reduction will increase after construction of the dam occurs because the water velocity will decrease and because the settling time will increase.

\section{Acknowledgements}

This research was supported by the graduate assistant fellowship program (GAFP) and the Department of Civil, Construction, and Environmental Engineering at the University of Alabama at Birmingham. The authors also thank the Egyptian Housing Building Research Center for their help in collecting samples and performing the chemical analyses.

\section{References}

[1] Abdo, M.H. (2013) Physico-Chemeical Studies on the Pollutants Effect in the Aquatic Environment of Rosetta Branch River Nile, Egypt. Life Science Journal, 10, 493-501.

[2] Donia, N. (2005) Rosetta Branch Waste Load Allocation Model. 9th International Water Technology Conference, Sharm El-Sheikh, 7-20 March 2005.

[3] Abdel-Wahaab, R. (1995) Wastewater Treatment and Reuse; Environmental Health and Safety Consideration. International Journal of Environmental Health Research, 5, 2-13.

[4] Abdel-Shafy, H.I. and Aly, R.O. (2002) Water Issues in Egypt Resources, Pollution and Protection Endeavors. Central European Journal of Occupational and Environmental Medicine, 8, 3-21.

[5] Ezzat, S.M. and Reham, M.E. (2012) Omar Bek Drain Water Quality and Its Impact on Damietta Branch, River NileEgypt. American-Eurasian Journal of Agricultural \& Environmental Sciences, 12, 472-483.

[6] Mostafa, M. (2014) Modeling of Pollutant Transport in the Nile Delta Egypt. Ph.D. Dissertation, University of Alabama at Birmingham, USA.

[7] El-Alfy, K.S. (2004) Surface Discharges of Warm Water from Thermal Power Stations into Rivers. 8th International Water Technology Conference, Alexandria, 26-28 March 2004.

[8] El-Sebaie, O.D., Abd El-Kerim, G.E., Ramadan, M.H., Abd El-Atey, M.M. and Taha, S.A. (2002) Water Treatment Plants Assessment at Talkha Power Plant. Journal of the Egyptian Public Health Association, 77, 347-370.

[9] Soltan, M.E. and Awadallah, R.M. (1995) Chemical Survey on the River Nile Water from Aswan into the Outlet. Journal of Environmental Science and Health, 30, 1647-1658. http://dx.doi.org/10.1080/10934529509376293

[10] Abd-Allah, A.M.A., Hamed, M.A. and Hassanain, M.M. (1999) Quality Criteria of the River Nile Water, Damietta Branch between Mansoura City and Damietta Province. Modelling, Measurement and Control C, 60, 1.39-1.51.

[11] Clesceri, L.S., Greenberg, A.E. and Trussell, R.R. (1989) Standard Methods for the Examination of Water and Wastewater. 17th Edition, American Public Health Association, Washington DC.

[12] National Water Research Center (1995) River Nile Protection and Development Project Phase II, Environmental Pollu- 
tion and Legislative Regulations (Law 48. 1982 \& Decree 8, 1993). Ministry of Public Works and Water Resources.

[13] U.S. Environmental Protection Agency (2007) Drinking Water Standards and Health Advisories Table. San Francisco. http://www.epa.gov/region9/water/drinking/files/dwsha_0607.pdf

[14] Bitton, G. (2011) Wastewater Microbiology. John Wiley \& Sons, Inc., Hoboken. 